\title{
Effect of Integrated Nutrient Management on Growth and Yield of Radish (Raphanus sativus L.) cv. Pusa Chetki
}

\author{
P. Jaisankar* \\ Department of Horticulture, Faculty of Agriculture, Annamalai University, \\ Annamalai nagar-608 002, Tamilnadu, India \\ *Corresponding author
}

\section{Keywords}

Radish, Organic manure, Biofertilizer, Growth, Yield

\section{Article Info}

Accepted:

07 October 2018

Available Online:

10 November 2018

\section{A B S T R A C T}

A field experiment was conducted in 2014 at farmer's field in Varagoorpettai village, Cuddalore, Tamilnadu to study the effect of integrated nutrient management on growth and yield of radish (Raphanus sativus L.) cv. pusa chetki. The experiment was laid out in Randomized Block Design with three replications and ten treatments. The treatment combination consisted of a organic manures (FYM and Vermicompost) Bio-fertilizer (Azospirillum) and Plant bio regulator (Humic acid). The treatment details viz., $\mathrm{T}_{1}$ - FYM @17.5 tha ${ }^{-1}+$ Azospirillum @ $5 \mathrm{~kg} \mathrm{ha}^{-1}+$ Humic acid @0.1\% ha ${ }^{-1}, \mathrm{~T}_{2}-\mathrm{FYM} @ 17.5 \mathrm{t}$ $\mathrm{ha}^{-1}+$ Azospirillum@5 kg ha ${ }^{-1}+$ Humic acid@0.2\% ha ${ }^{-1}, \mathrm{~T}_{3}-\mathrm{FYM} @ 25 \mathrm{t} \mathrm{ha}^{-1}+$ Azospirillum@5 kg ha ${ }^{-1}+$ Humic acid @ $0.1 \% \mathrm{ha}^{-1}, \mathrm{~T}_{4}$ - FYM @ $25 \mathrm{t} \mathrm{ha}^{-1}+$ Azospirillum @ $5 \mathrm{~kg} \mathrm{ha}^{-1}+$ Humic acid @ $0.2 \% \mathrm{ha}^{-1}, \mathrm{~T}_{5}$ - Vermicompost $10 \mathrm{t} \mathrm{ha}^{-1}+$ Azospirillum @ 5 $\mathrm{kg} \mathrm{ha}^{-1}+$ Humic acid @0.1\% ha ${ }^{-1}, \mathrm{~T}_{6}$ - Vermicompost $10 \mathrm{t} \mathrm{ha}^{-1}+$ Azospirillum @ $5 \mathrm{~kg}$ $\mathrm{ha}^{-1}+$ Humic acid @ $0.2 \% \mathrm{ha}^{-1}, \mathrm{~T}_{7}$-Vermicompost $12.5 \mathrm{tha}^{-1}+$ Azospirillum @ $5 \mathrm{~kg} \mathrm{ha}^{-1}$ +Humic acid@0.1\% ha ${ }^{-1}, \mathrm{~T}_{8}$-Vermicompost $12.5 \mathrm{t} \mathrm{ha}^{-1}+$ Azospirillum @ $5 \mathrm{~kg} \mathrm{ha}^{-1}+$ Humic acid@0.2\%, T - Recommended dose of NPK @ 80:40: $80 \mathrm{~kg} \mathrm{ha}^{-1}$ and $\mathrm{T}_{10}$ Absolute Control. Among the treatment significantly influenced on application of Vermicompost $12.5 \mathrm{t} \mathrm{ha}^{-1}$ + Azospirillum @ $5 \mathrm{~kg} \mathrm{ha}^{-1}$ + Humic acid @ $0.2 \% \mathrm{ha}^{-1}\left(\mathrm{~T}_{8}\right)$ resulted in maximum values of growth and yield attributes viz., days taken for germination (3.12), shoot length $(43.56 \mathrm{~cm})$, number of leaves per plant (14.68 DAS), leaf area (185.86), shoot weight $(56.23 \mathrm{~g})$, crop dry matter production $(26.13 \mathrm{~g})$. root length (15.63 $\mathrm{cm})$, root girth $(3.11 \mathrm{~cm})$, root weight $(161.59 \mathrm{~g})$ and root yield per plot $(4.09 \mathrm{~kg})$, ascorbic

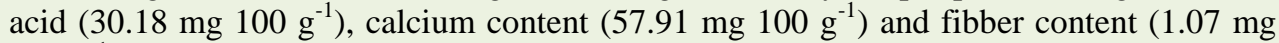
$\left.100 \mathrm{~g}^{-1}\right)$ quality characters. Application of Vermicompost $12.5 \mathrm{t}$ ha-1 + Azospirillum @ 5 $\mathrm{kg} \mathrm{ha}{ }^{-1}+$ Humic acid @ $0.2 \% \mathrm{ha}^{-1}$ is recommended to get higher yield in radish.

\section{Introduction}

Radish (Raphanus sativus L.) is one of the most important root crops belonging to the family Cruciferae. It is grown both in tropical and temperate regions of the world and is probably a native of Europe and Asia. Radish is grown for its edible young, tender and fusiform roots which are eaten raw as a salad or cooked as a vegetable. It is a good source of minerals, vitamins $\mathrm{A}$ and $\mathrm{C}$ and medicinal properties. Organic agriculture is gaining movement in India due to the individual as well as group efforts to conserve environments 
and avoid contamination of the farm produce from the use of chemical fertilizers and pesticides. The important tenet of the organic food movement is it promotes ecological soundness and sustainable use of natural resource, also maintenance of crop diversity. Farmyard manure being a bulky organic material releases the soil compaction and improves the aeration in addition to the supply of essential plant nutrients and organic matter, thereby increasing the soil microbial establishment along with the accumulation of excess humus content. Vermicompost provides vital macronutrients $\left(\mathrm{N}, \mathrm{P}_{2} \mathrm{O}_{5}, \mathrm{~K}_{2} \mathrm{O}\right.$, $\mathrm{Ca}$ and $\mathrm{Mg}$ ) and micronutrient $\mathrm{Fe}, \mathrm{Mn}, \mathrm{Zn}$ and $\mathrm{Cu}$ ). The chemical analysis of Vermicompost reveals that the $\mathrm{N}, \mathrm{P}_{2} \mathrm{O}_{5}, \mathrm{~K}_{2} \mathrm{O}$, content was 0.8 , 1.1, 0.5, respectively (Giraddi et al., 1993). Humic acid influence the plant growth by modifying the physiology of plants and improving the physical, chemical and biological properties of soil. Humic acid is reported to increase the permeability of plant membranes, resulting in higher metabolic activity. Biofertilizer or microbial inoculants are eco- friendly, non-bulky, cheap and renewable sources of nutrients for plants. The application of bio-fertilizers also helps in improving biological activities of soil. Nitrogen-fixing bacteria belonging to genus Azospirillum is known to increase the yield by 5 to 20 percent with a saving of nitrogen up to 40 percent of the recommended dose (Dart, 1986). Azospirillum not only fixes biological nitrogen but also produces a growth regulator like substance (Sundaravelu and Muthukrishnan, 1993). The integrated nutrient management system approach utilizes a judicious combination of inorganic fertilizers and organic manures in building soil fertility and to increase the production potential of any crop (Khalid et al., 2015). Moreover, this approach is economically cheap, technically sound, practically feasible and is capable of maintaining the sustainability in production. Therefore, integrated nutrient management practice is the only answer for the production of good quality of tuber yield. Keeping in view the above facts in mind, the present studies have been planned to use organic, inorganic and biofertilizers on growth and yield contributing characters of radish.

\section{Materials and Methods}

The study was conducted during 2015 at farmer field in Varagoorpettai village,

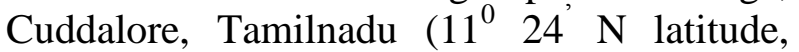
$75^{\circ} 11^{\prime} \mathrm{E}$ longitude and $+5.70 \mathrm{~m}$ MSL above mean sea level). The soil was sandy loam in texture, alkaline in reaction ( $\mathrm{pH}$ 5.74) low in available nitrogen $\left(192.7 \mathrm{~kg} \mathrm{ha}^{-1}\right)$, medium in available phosphorus $\left(18.5 \mathrm{~kg} \mathrm{P}_{2} \mathrm{O}_{5} \mathrm{ha}^{-1}\right)$ and higher in available potassium $\left(299.0 \mathrm{~kg} \mathrm{~K}_{2} \mathrm{O}\right.$ $\mathrm{ha}^{-1}$ ). Thus ten treatments were laid out in Randomized Block Design with three replications. The treatment combination consisted of an organic manures (FYM and Vermicompost) Bio-fertilizer (Azospirillum) and Plant bio regulator (Humic acid), Recommended dose of NPK (80:40: 80) and along with control.

Treatment details viz., $\mathrm{T}_{1}$ - FYM @ $17.5 \mathrm{t} \mathrm{ha}^{-1}$ +Azospirillum@5 kg ha ${ }^{-1}+$ Humic acid@ $0.1 \% \mathrm{ha}^{-1}, \mathrm{~T}_{2}$ - FYM @ $17.5 \mathrm{t} \mathrm{ha}^{-1}+$ Azospirillum @ $5 \mathrm{~kg} \mathrm{ha}^{-1}+$ Humic acid @ 0.2 $\% \mathrm{ha}^{-1}, \mathrm{~T}_{3}$ - FYM @ $25 \mathrm{t} \mathrm{ha}^{-1}+$ Azospirillum @ $5 \mathrm{~kg} \mathrm{ha}^{-1}+$ Humic acid @ $0.1 \% \mathrm{ha}^{-1}, \mathrm{~T}_{4}-$ FYM@ $25 \mathrm{t} \mathrm{ha}^{-1}+$ Azospirillum @ $5 \mathrm{~kg} \mathrm{ha}^{-1}+$ Humic acid @ $0.2 \% \mathrm{ha}^{-1}, \mathrm{~T}_{5}$ - Vermicompost $10 \mathrm{t} \mathrm{ha}^{-1}+$ Azospirillum @ $5 \mathrm{~kg} \mathrm{ha}^{-1}+$ Humic acid@0.1\% ha $\mathrm{h}^{-1}, \mathrm{~T}_{6}$ - Vermicompost $10 \mathrm{t}$ $\mathrm{ha}^{-1}+$ Azospirillum @ $5 \mathrm{~kg} \mathrm{ha}^{-1}+$ Humic acid @ $0.2 \% \mathrm{ha}^{-1}, \mathrm{~T}_{7}$-Vermicompost $12.5 \mathrm{t} \mathrm{ha}^{-1}+$ Azospirillum @ $5 \mathrm{~kg} \mathrm{ha}^{-1}+$ Humic acid @ 0.1 $\% \mathrm{ha}^{-1}, \mathrm{~T}_{8}$-Vermicompost $12.5 \mathrm{t} \mathrm{ha}^{-1}+$ Azospirillum @ $5 \mathrm{~kg} \mathrm{ha}^{-1}+$ Humic acid @ 0.2 $\%, \mathrm{~T}_{9}$ - Recommended dose of NPK @ 80:40: $80 \mathrm{~kg} \mathrm{ha}^{-1}$ and $\mathrm{T}_{10}$ - Absolute Control. The Radish (cv. Pusa Chetki) seeds were sown during mid-December in $1 \mathrm{~m}$ x $2 \mathrm{~m}$ plot size. 
The experiment field was supplied with well rotten farmyard manure $\left(20 \mathrm{t} \mathrm{ha}^{-1}\right)$. The observations were recorded on five randomly selected plants from each plot on different growth and yield characters like days taken for germination, number of leaves per plant (DAS), leaf area, crop dry matter production $(\mathrm{g})$. root length $(\mathrm{cm})$, root girth $(\mathrm{cm})$, root weight $(\mathrm{g})$ and root yield per plot $(\mathrm{kg})$ ascorbic acid (mg $100 \mathrm{~g}^{-1}$ ), calcium content (mg 100 $\mathrm{g}^{-1}$ ) and fiber content (mg $100 \mathrm{~g}^{-1}$ ) (Table 1 and 2). The data was analyzed by adopting the standard procedure of Panse and Sukhatme (1985) and using AGRISTAT software. Wherever, the results were found significant, critical differences (CD) were computed at 5 percent level of probability to draw statistical conclusions.

\section{Results and Discussion}

\section{Growth characters}

The results of the present investigation showed that there was a significant difference on the growth parameters, viz., days taken for germination, shoot length, number of leaves, leaf area, shoot weight and crop dry matter production (Table 1). The days taken for germination (3.12 DAS) was found to be early in the treatment which received Vermicompost 12.5 tonnes $\mathrm{ha}^{-1}+$ Azospirillum @ $5 \mathrm{~kg} \mathrm{ha}^{-1}+$ Humic acid @ $0.2 \% \mathrm{ha}^{-1}\left(\mathrm{~T}_{7}\right)+$ whereas the days taken for germination was delayed in control. Vermicompost resulting from degradation of organic waste which is rich in nutrient content and growth promoting substances may fit well in integrated nutrient management for crop germination. This was in line with the result of Kamalakar Reddy and Venkata Rao (2004). The shoot length (43.56 $\mathrm{cm}$ and 45 DAS) was found to be increased significantly due to the application of Vermicompost 12.5 tonnes $\mathrm{ha}^{-1}+$ Azospirillum @ $5 \mathrm{~kg} \mathrm{ha}^{-1}+$ Humic acid @ $0.2 \% \mathrm{ha}^{-1}\left(\mathrm{~T}_{8}\right)$ was recorded to be the highest when compared to other treatments. Application of 50 percent RDF of NPK plus vermicompost at the rate of $2 \mathrm{t} \mathrm{ha}^{-1}$ plus Azospirillum and phosphobacteira increased the vine length, earliness in flowering and yield in cucumber (Prabu et al., 2010). The number of leaves per plant and leaf area showed significant variations in the crop. The results of the investigation revealed that application of Vermicompost 12.5 tonnes ha $^{-1}$ +Azospirillum@ $5 \mathrm{~kg} \mathrm{ha}^{-1}+$ Humic acid@ $0.2 \% \mathrm{ha}^{-1}\left(\mathrm{~T}_{8}\right)$ increased the number of leaves (14.68 and 45 DAS) and leaf area (185.86 $\left.\mathrm{cm}^{2}\right)$ when compared to $\left(\mathrm{T}_{10}\right)$. The increase in a number of leaves may be due to the vital macro and micronutrient availability with vermicompost.

This was on the line with the result (Giraddi, 1993). Increasing trend in the shoot weight and dry matter production were recorded in the present investigation. The application of Vermicompost 12.5 tonnes $\mathrm{ha}^{-1}+$ Azospirillum @ $5 \mathrm{~kg} \mathrm{ha}{ }^{-1}+$ Humic acid @ $0.2 \% \mathrm{ha}^{-1}$ envisaged maximum shoot weight $(56.23 \mathrm{~g}$ plant $^{-1}$ ) and dry matter production $(26.13 \mathrm{~g}$ plant $^{-1}$ ) in $\mathrm{T}_{8}$ whereas it was recorded to be minimum in $\mathrm{T}_{10}$ (Control). Enhancement in the growth attributes due to Vermicompost in the present research is in line with the reports of Rajamanickam et al., (2008) who revealed enhanced growth parameter in plants grown in the potting mixture, treated with vermicompost.

\section{Yield and quality attributes}

Regarding the yield attributes of radish (Table $2)$, in respect to root length and root girth, the maximum $(15.63 \mathrm{~cm})$ root length was found with the application of Vermicompost 12.5 tonnes $\mathrm{ha}^{-1}+$ Azospirillum @ $5 \mathrm{~kg} \mathrm{ha}^{-1}+$ Humic acid@0.2\% $0 \mathrm{ha}^{-1}\left(\mathrm{~T}_{8}\right)$. The maximum root girth $(3.11 \mathrm{~cm})$ was recorded in which Vermicompost 12.5 tonnes $\mathrm{ha}^{-1}+$ Azospirillum @ 5 kg ha ${ }^{-1}+$ Humic acid @ $0.2 \% \mathrm{ha}^{-1}\left(\mathrm{~T}_{8}\right)$ was applied. 
Table.1 Effect of integrated nutrient management and growth Characters of radish cv. Pusa Chetki

\begin{tabular}{|c|c|c|c|c|c|c|c|}
\hline $\begin{array}{l}\text { S. } \\
\text { No. }\end{array}$ & Treatment description & $\begin{array}{l}\text { Number of } \\
\text { days taken } \\
\quad \text { for } \\
\text { germination }\end{array}$ & $\begin{array}{l}\text { Shoot } \\
\text { length } \\
(\mathrm{cm})\end{array}$ & $\begin{array}{c}\text { Number } \\
\text { of } \\
\text { leaves }\end{array}$ & $\begin{array}{l}\text { Leaf } \\
\text { area } \\
\left(\mathrm{cm}^{2}\right)\end{array}$ & $\begin{array}{c}\text { Shoot } \\
\text { weight } \\
(\mathrm{g} \\
\left.\text { plant }^{-1}\right)\end{array}$ & $\begin{array}{l}\text { Crop dry } \\
\text { matter } \\
\text { production } \\
\left(\text { g plant }^{-1}\right)\end{array}$ \\
\hline $\mathbf{T}_{1}$ & $\begin{array}{l}\text { FYM@ } 17.5 \text { tonnes ha }{ }^{-1}+ \\
\text { Azospirillum@ } 5 \mathrm{~kg} \mathrm{ha}^{-1}+\text { Humic } \\
\text { acid@0.1\% } \mathrm{ha}^{-1}\end{array}$ & 4.87 & 35.71 & 11.27 & 136.21 & 47.36 & 23.64 \\
\hline $\mathbf{T}_{2}$ & $\begin{array}{l}\text { FYM@ } 17.5 \text { tonnes ha }{ }^{-1}+ \\
\text { Azospirillum } 55 \mathrm{~kg} \mathrm{ha}^{-1}+\text { Humic } \\
\text { acid@ } 0.2 \% \mathrm{ha}^{-1}\end{array}$ & 4.40 & 38.47 & 12.24 & 14.03 & 52.65 & 24.73 \\
\hline $\mathbf{T}_{3}$ & $\begin{array}{l}\text { FYM@25 tonnes ha-1 } \\
\text { Azospirillum@ } 5 \mathrm{~kg} \mathrm{ha}^{-1}+\text { Humic } \\
\text { acid@ } 0.1 \% \mathrm{ha}^{-1}\end{array}$ & 3.88 & 40.44 & 12.68 & 165.12 & 53.27 & 24.93 \\
\hline $\mathbf{T}_{4}$ & $\begin{array}{l}\text { FYM@25 tonnes ha }{ }^{-1}+ \\
\text { Azospirillum @ } 5 \mathrm{~kg} \mathrm{ha}^{-1}+\text { Humic } \\
\text { acid@ } 0.2 \% \mathrm{ha}^{-4}\end{array}$ & 4.86 & 35.73 & 11.52 & 136.18 & 47.30 & 23.64 \\
\hline $\mathbf{T}_{5}$ & $\begin{array}{l}\text { Vermicompost } 10 \text { tonnes ha- }{ }^{-1}+ \\
\text { Azospilillum @ } 5 \mathrm{~kg} \mathrm{ha}^{-1}+ \\
\text { Humic acid @ } 0.1 \% \mathrm{ha}^{-1}\end{array}$ & 4.84 & 35.45 & 11.72 & 138.28 & 47.27 & 23.63 \\
\hline $\mathbf{T}_{6}$ & $\begin{array}{l}\text { Vermicompost } 10 \text { tonnes } \mathrm{ha}^{-1}+ \\
\text { Azospilillum @ } 5 \mathrm{~kg} \mathrm{ha}^{-1}+ \\
\text { Humic acid @ } 0.2 \% \mathrm{ha}^{-1}\end{array}$ & 5.56 & 34.78 & 10.26 & 131.16 & 42.60 & 22.62 \\
\hline $\mathbf{T}_{7}$ & $\begin{array}{l}\text { Vermicompost } 12.5 \text { tonnes ha }^{-1}+ \\
\text { Azospilillum @ } 5 \mathrm{~kg} \mathrm{ha}^{-1}+ \\
\text { Humic acid @ } 0.1 \% \mathrm{ha}^{-1}\end{array}$ & 3.48 & 41.74 & 13.51 & 175.35 & 54.58 & 25.58 \\
\hline $\mathbf{T}_{8}$ & $\begin{array}{l}\text { Vermicompost } 12.5 \text { tonnes } \mathrm{ha}^{-1}+ \\
\text { Azospilillum @ } 5 \mathrm{~kg} \mathrm{ha}^{-1}+ \\
\text { Humic acid @ } 0.2 \% \mathrm{ha}^{-1}\end{array}$ & 3.12 & 43.56 & 14.68 & 185.86 & 56.23 & 26.13 \\
\hline $\mathbf{T}_{9}$ & $\begin{array}{l}\text { Recommended dose of NPK @ } \\
\text { 80:40:80 kg ha }\end{array}$ & 3.94 & 40.53 & 12.65 & 165.92 & 53.21 & 24.92 \\
\hline $\mathbf{T}_{10}$ & Absolute Control & 6.20 & 28.44 & 9.52 & 125.04 & 39.60 & 21.85 \\
\hline & S.Ed & 0.10 & 0.19 & 0.18 & 2.18 & 0.14 & 0.09 \\
\hline & C.D $(p=0.05$ & 0.21 & 0.38 & 0.38 & 4.59 & 0.29 & 0.21 \\
\hline
\end{tabular}


Table.2 Effect of integrated nutrient management and yield attributes of radish cv. Pusa Chetki

\begin{tabular}{|c|c|c|c|c|c|c|c|c|}
\hline $\begin{array}{l}\text { S. } \\
\text { No. }\end{array}$ & Treatment description & $\begin{array}{l}\text { Root } \\
\text { length } \\
(\mathrm{cm})\end{array}$ & $\begin{array}{l}\text { Root } \\
\text { girth } \\
(\mathrm{cm})\end{array}$ & $\begin{array}{c}\text { Root } \\
\text { weight } \\
\left(\text { g plant }^{-1}\right)\end{array}$ & $\begin{array}{l}\text { Root yield } \\
\left(\text { kg plot }^{-1}\right)\end{array}$ & $\begin{array}{c}\text { Ascorbic } \\
\text { acid } \\
\text { content } \\
\left(\mathbf{m g} 100 \mathrm{~g}^{-1}\right)\end{array}$ & $\begin{array}{l}\text { Calcium } \\
\text { content } \\
\left(\mathrm{mg} 100 \mathrm{~g}^{-1}\right)\end{array}$ & $\begin{array}{l}\text { Fibre } \\
\text { content } \\
\left(\mathrm{g} 100 \mathrm{~g}^{-}\right. \\
1 \text { ) }\end{array}$ \\
\hline $\mathrm{T}_{1}$ & $\begin{array}{l}\text { FYM@17.5 tonnes ha }{ }^{-1}+ \\
\text { Azospirillum@ } 5 \mathrm{~kg} \mathrm{~h}^{-1}+ \\
\text { Humic acid@0.1\% ha }\end{array}$ & 12.49 & 2.09 & 149.71 & 2.62 & 22.66 & 50.57 & 2.79 \\
\hline $\mathbf{T}_{2}$ & $\begin{array}{l}\text { FYM@17.5 tonnes ha }{ }^{-1}+ \\
\text { Azospirillum@ } 5 \mathrm{~kg} \mathrm{ha}^{-1}+ \\
\text { Humic acid@ } 0.2 \% \mathrm{ha}^{-1}\end{array}$ & 13.20 & 2.31 & 153.48 & 2.96 & 24.18 & 52.61 & 2.08 \\
\hline $\mathbf{T}_{3}$ & $\begin{array}{l}\text { FYM@25 tonnes ha- }{ }^{-1}+ \\
\text { Azospirillum@5 kg ha }{ }^{-1}+ \\
\text { Humic acid@0.1\% ha }{ }^{-1}\end{array}$ & 13.87 & 2.49 & 154.56 & 3.09 & 26.14 & 54.63 & 1.92 \\
\hline $\mathbf{T}_{4}$ & $\begin{array}{l}\text { FYM@25 tonnes ha-1 }+ \\
\text { Azospirillum@5 kg ha-1 } \\
\text { Humic acid@0.2\% } \mathrm{ha}^{-4}\end{array}$ & 12.52 & 2.14 & 149.75 & 2.54 & 22.65 & 50.71 & 2.85 \\
\hline $\mathbf{T}_{5}$ & $\begin{array}{l}\text { Vermicompost } 10 \text { tonnes ha }{ }^{-1} \\
+ \text { Azospilillum @ } 5 \mathrm{~kg} \mathrm{ha}^{-1}+ \\
\text { Humic acid @ } 0.1 \% \mathrm{ha}^{-1}\end{array}$ & 12.59 & 2.10 & 149.72 & 2.56 & 22.61 & 50.65 & 2.86 \\
\hline $\mathbf{T}_{6}$ & $\begin{array}{l}\text { Vermicompost } 10 \text { tonnes ha }{ }^{-1} \\
+ \text { Azospilillum @ } 5 \mathrm{~kg} \mathrm{ha}^{-1}+ \\
\text { Humic acid @ } 0.2 \% \mathrm{ha}^{-1}\end{array}$ & 11.57 & 1.93 & 146.50 & 2.07 & 19.29 & 49.95 & 3.04 \\
\hline $\mathbf{T}_{7}$ & $\begin{array}{l}\text { Vermicompost } 12.5 \text { tonnes } \\
\mathrm{ha}^{-1}+\text { Azospilillum } @ 5 \mathrm{~kg} \mathrm{ha}^{-} \\
{ }^{1}+\text { Humic acid @ } 0.1 \% \mathrm{ha}^{-1}\end{array}$ & 14.64 & 2.81 & 158.63 & 3.83 & 28.62 & 55.90 & 1.51 \\
\hline $\mathbf{T}_{8}$ & $\begin{array}{l}\text { Vermicompost } 12.5 \text { tonnes } \\
\mathrm{ha}^{-1}+\text { Azospilillum @ } 5 \mathrm{~kg} \mathrm{ha}^{-} \\
{ }^{1}+\text { Humic acid @ } 0.2 \% \mathrm{ha}^{-1}\end{array}$ & 15.63 & 3.11 & 161.59 & 4.09 & 30.18 & 57.91 & 1.07 \\
\hline $\mathbf{T}_{9}$ & $\begin{array}{l}\text { Recommended dose of NPK } \\
\text { @ 80:40:80 kg ha }\end{array}$ & 13.83 & 2.45 & 154.53 & 3.11 & 26.14 & 54.71 & 1.97 \\
\hline \multirow[t]{3}{*}{$\mathbf{T}_{10}$} & Absolute Control & 10.46 & 1.46 & 142.49 & 1.76 & 17.23 & 49.06 & 3.38 \\
\hline & S.Ed & 0.13 & 0.04 & 0.19 & 0.04 & 0.07 & 0.06 & 0.04 \\
\hline & C.D $(p=0.05$ & 0.28 & 0.09 & 0.39 & 0.10 & 0.16 & 0.16 & 0.09 \\
\hline
\end{tabular}

Earthworms play a great role in increasing the soil fertility was productivity by decomposing and converting organic waste into useful compost which may benefit for developing root length and root girth (Khutate et al., 2006). In the present study maximum root weight of $\left(161.59 \mathrm{~g} \mathrm{plant}^{-1}\right)$ and root yield of $\left(4.09 \mathrm{~kg} \mathrm{plot}^{-1}\right)$ was recorded in the treatment Vermicompost 12.5 tonnes $\mathrm{ha}^{-1}+$ Azospirillum @ $5 \mathrm{~kg} \mathrm{ha}^{-1}+$ Humic acid @ 0.2 $\% \mathrm{ha}^{-1}\left(\mathrm{~T}_{8}\right)$ was applied. Application of Vermicompost@5 t ha ${ }^{-1}$ combined with consortium fertilizer @ $2 \mathrm{~kg} \mathrm{ha}^{-1}$ plus foliar application of EM @ 1:1000 dilutions and PK @ 3\% found to have a beneficial effect on growth and yield of radish (Subramani, 2010). With respect to quality characters of radish in this study it was found that the maximum ascorbic acid (30.18 mg 100 $\left.{ }^{-1}\right)$ was recorded in the treatment which involved Vermicompost 12.5 tonnes $\mathrm{ha}^{-1}+$ Azospirillum @ $5 \mathrm{~kg} \mathrm{ha}^{-1}+$ Humic acid @ 0.2 $\% \mathrm{ha}^{-1}\left(\mathrm{~T}_{8}\right)$. The calcium content $(57.91 \mathrm{mg}$ $100 \mathrm{~g}^{-1}$ ) was also recorded the highest in this treatment $\left(\mathrm{T}_{8}\right)$. However, the fiber content in treatment with Vermicompost 12.5 tonnes $\mathrm{ha}^{-1}+$ Azospirillum @ $5 \mathrm{~kg} \mathrm{ha}^{-1}+$ Humic acid @ $0.2 \% \mathrm{ha}^{-1}\left(\mathrm{~T}_{8}\right)$ was significantly reduced

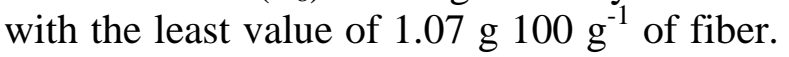
Best performance of the treatment with 
highest values quality parameters in the present study due to addition of integrated nutrition like vermicompost, Azospirillum and humic acid might be due to the reason that these integrated nutrient components contain major and minor nutrient in available forms to plants, enzymes, antibiotics, vitamins, beneficial microorganisms and other organic manures (Meerabai et al., 2001).

In the present investigation, supplementation of radish with organic fertilizers along with bio-fertilizer and plant bio regulator resulted in higher growth and yield parameters. Therefore, to produce a sustainable higher yield of radish it is recommended to make use of Vermicompost 12.5 tonnes $\mathrm{ha}^{-1}+$ Azospirillum @ $5 \mathrm{~kg} \mathrm{ha}^{-1}+$ Humic acid @ 0.2 $\% \mathrm{ha}^{-1}\left(\mathrm{~T}_{8}\right)$ to enhance growth and yield in addition to improve soil fertility in radish cultivation.

\section{References}

Dart, P.J. 1986. Nitrogen fixation associated with non-legumes in agriculture Plant and Soil. 90: 303-334.

Giraddi, 1993. Vermiculture and role in agriculture. In: Proc. Course on the officers of the state Department of Agriculture, Karnataka, 18-20 October by the Department of Agriculture Microbiology, University of Agriculture Sciences, Dharwad, pp. 50-54.

Kamalakar Reddy, P. and P. Venkata Rao., 2004. Growth and yield of bitter gourd (Momordica charantia L.) as influenced by vermicompost and nitrogen management practices. J. Res. ANGRAU., 32(3): 15-20.
Khalid M, Yadav BK, Yadav MP. Studies on the effect of integrated nutrient management on growth and yield attributes of radish (Raphanus sativus L.). Ann. Hort. 2015; 8(1): 81-83.

Khutate, S.V., M.V. Patel, D.D. Mokashi and J.D. Jadhav. 2006. Influence of vermicompost on quality parameters and soil fertility status of sweet corn. J. Soils and Crops, 16(2): 384-389.

Meerabai, M. and Raj 2001. Biofarming in vegetables. Kisan World, 28(4): 15.

Panse VG, and Sukhtme PV. Statistical Methods for Agricultural Workers. ICAR, New Delhi, 145-155.

Prabhu, M., A. Ramesh Kumar and K. Rajamani. 2010. Influence of different organic substances on growth and herbage yield on Sacred basil (Ocimum sanctum) Indian J. Agri. Res., 44(1): 4852.

Rajamanickam, C., Balasubramanian, S. and Natarajan, S. 2008. Studies on nursery management in papaya (Carica papaya L.) $\mathrm{cv}$. Co2, proceedings of second international symposium on papaya, pp.74.

Subramani, A. 2010. Effect of organic nutrients on growth and yield of radish (Raphanus sativus L.), M.Sc., (Ag.) Hort. Thesis, Annamalai University, Annamalainagar.

Sundaravelu, S. and T. Muthukrishnan, 1993. Effect of seed treatment with Azospirillum and gibberellic acid on the growth and yield of radish (Raphanus sativus L. var. Japanese white). South Indian Hort., 41(4): 212-213.

\section{How to cite this article:}

Jaisankar, P. 2018. Effect of Integrated Nutrient Management on Growth and Yield of Radish (Raphanus sativus L.) cv. Pusa Chetki. Int.J.Curr.Microbiol.App.Sci. 7(11): 461-466. doi: https://doi.org/10.20546/ijcmas.2018.711.054 